NORDISK MUSEOLOGI $1996 \cdot 2$, S. 35-40

\title{
EKOMUSEET \\ I EN FRAMTIDSVISION
}

\author{
Ewa Bergdahl
}

Egentligen handlar allt arbete kring historiska frågor - alltsä även olika slags museiverksambet - om ett förhållningssätt till det som passerat. Benägenheten att se tillbaka i backspegeln har skiftat genom tiderna och skiftar även i forrhallande till vem du är och hur det sambälle ser ut som omger dig. Nordiska museets motto "Känn dig själv» och Svenska Turistföreningens kampanj "Känn ditt land» är tydliga exempel på hur man tidigt varit medveten om detta. Och när hembygdsrörelsen i Sverige tog fart efter sekelskiftet gällde parollen "Arbeta ej $i$ det förflutna utan for framtiden». Det är alltså inte någon ny tanke att museiarbete siktar mot framtiden. Uifrån en polarisering av begreppen «kropp» och «själ» ska jag forrsöka beskriva hur ekomuseiidén kan utvecklas i framtiden.

Museerna och arkiven utgör ett samhälles kollektiva minne. Men det finns mycket som inte ryms vare sig $\mathrm{i}$ arkiv eller $\mathrm{i}$ museimagasin. I Sverige har vi en portalparagraf $\mathrm{i}$ vår kulturminneslag som slår fast att bevarandet av det kulturhistoriska arvet är allas vårt ansvar. Det kollektiva minnet ska därför tolkas som betydligt mer än museernas och arkivens innehåll. All mänsklig erfarenhet och kunskap, alla arbetsprocesser och alla uttrycksmedel som människor skapat, tillhör tillsammans med vår fysiska miljö, de delar av det kollektiva minnet som inte ryms $\mathrm{i}$ arkivrummen.

Ekomuseernas framväxt under 1970-talet ser jag som en följd av denna insikt. Att många ekomuseer kom att handskas med industrisamhällets historia har säkert sin förklaring i det faktum att varken de fysiska industrianläggningarna eller arbetskraftens kunskaper och erfarenheter låter sig insamlas och dokumenteras på traditionellt vis.

Det kollektiva minnet i form av insamlat arkivmaterial eller insamlade och bevarade föremål i museerna utgör en konstruerad bild av historien, som har styrts av de insamlingsprinciper och värderingar som varit gängse under insamlingsarbetets gång. Man kan tydligt se detta i t.ex. registreringen av arkeologiska fynd från olika epoker. Värdet av det insamlade materialet är en kombination av speglingen av varje tids värderingar och bedömningar av vad som är värt att bevara till eftervärlden och naturligtvis även av samlingarnas faktiska materiella innehåll. Det 
EWA BERGDAHL

36 finns självklart stora värden i våra museisamlingar, men man får inte okritiskt tillskriva dem ett objektivt historiskt värde. Ett kulturlandskap däremot innehåller spåren efter äldre tiders verksamheter och utgör ett slags levande arkivmaterial. Här är det inte ett insamlande som avgjort vad som finns kvar att läsa, utan människors fortsatta användande av landskapet.

Det finns en grundläggande humanistisk syn i vården av fysiska värden. Men här döljer sig även en tydlig materialistisk filosofi. Liksom läkarvetenskapen idag försöker åstadkomma människans odödlighet, försöker vi i bevarandearbetet ge tingen ett evigt liv. Vi vårdar byggnader, miljöer och föremål med stor iver, men tyvärr många gånger på ett sådant sätt att de så småningom helt försvinner. Originaldel efter originaldel byts ut och en dag upptäcker vi slutligen att ursprungsobjektet har förvandlats till en kopia av sig självt. Själen har gått förlorad.

Varför gör vi så här? Varför betyder de fysiska objekten så mycket för oss?

Jag tror att det har att göra med den tid vi lever i och den materialism som präglar vår tid. Det som inte syns - finns inte. Därför blir också de yttre manifesta formerna viktiga - kanske alltför viktiga, så att vi tillmäter budskap och innehåll mindre betydelse. Ett industrihistoriskt kulturminne är ju även bärare både av branschens och ägarnas symbolspråk och av arbetets liv och kunskaper. När nedlagda industrianläggningar idag bevaras, blir det yttre symboliska skalet ofta det enda som påminner om den verksamhet som en gång pågått invändigt. Det är lätt att tappa bort historiens immateriella sidor. Ekomuseerna har här stora möjligheter, eftersom de inte är tyngda av ägandet eller för- valtandet av fysiska anläggningar, byggnader, industrier och föremål.

Ekomuseerna är exempel på museiorganisationer som istället lägger stor vikt vid människors aktiva deltagande i museiarbetet och som skapar möjligheter för alla att vara med och påverka. Men det gäller dock att hela tiden lyfta sig själv i håret för att verksamheterna, aktiviteterna och de levande historietolkningarna ska stå i fokus. Plattformen - eller scenen om man så vill - för arbetet utgörs av den geografiska regionen med sina spår av mänskligt liv. Det aktiva deltagandet av områdets invånare innebär emellertid inte automatiskt att arbetsmetoder och synsätt skiljer sig från de traditionella museerna. Till detta fordras en ständigt pågående och ifrågasättande diskussion av metoderna.

På 1970-talet lanserade Erik Hofrén som då var landsantikvarie i Dalarna begreppet grannskapsmuseum och slog fast att dess kärna var delaktighet. Några år senare anammade Statens kulturråd detta begrepp och använde det för att beskriva de "nya» museerna. Man talade redan då om människors roll i museet och använde termen «levandegöra» för att beskriva hur de kollektiva erfarenheterna skulle kunna förmedlas både till invånarna och till annan publik. I de första ekomuseerna fanns däremot inga uttalade turistiska ambitioner.

Att sträva efter att skapa en museiorganisation som inbjuder till delaktighet innebär samtidigt att verksamheterna, arrangemangen och förhållningssättet till den egna historien sätts i centrum. Det är att lägga tyngdpunkten på museets själ och odla den. Samtidigt måste verksamheterna, förhållningssätten och ideologierna speglas i den fysiska verkligheten och materialiseras i tillvaratagandet av histori- 


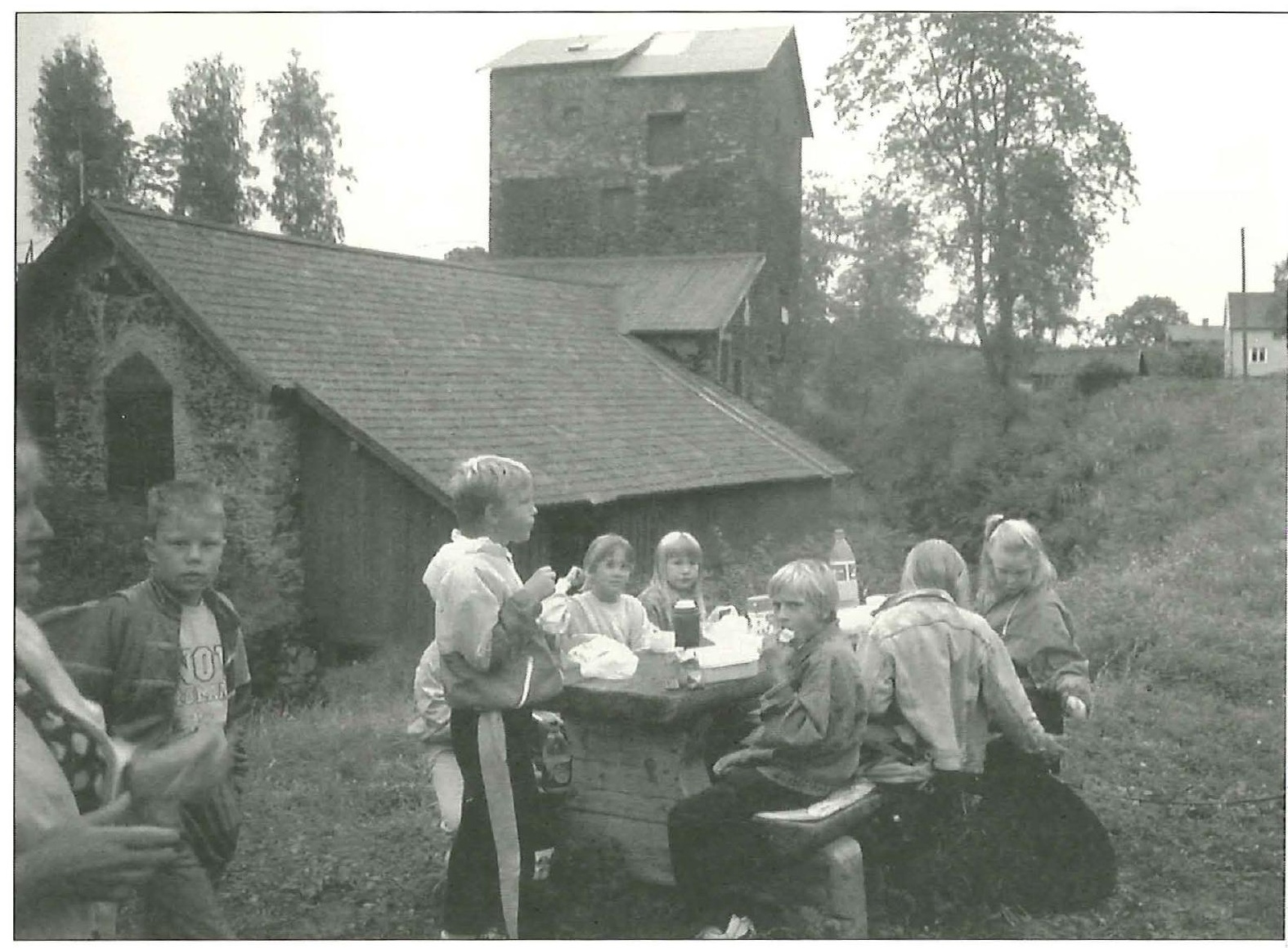

Ekomuseum Bergslagen. Skolbarn på besök vid Flatenbergs hytta. Foto: Örjan Hamrin.

ens spår. Museet måste därför även ha en fysisk kropp. Skulle det överhuvud taget gå att vidmakthålla ett kollektivt minne om vi inte kan se historiens spår i materialiserad form? Jag tror inte det.

Några faror i ekomuseernas arbete idag kan man skönja. Alltför mycket sysslande med museets "kropp», dvs. med de fysiska spåren i landskapet, kan innebära att kraften inte finns kvar till att föra diskussionerna och debatterna om vad historien betyder för oss vidare. Många svenska hembygdsföreningar lider av detta problem. All tid läggs ned på att fysiskt bevara hembygdsgårdarna och de stora föremålssamlingarna och ingen kraft finns kvar vare sig till att vidga deltagandet i föreningarnas arbete eller att diskutera meningen med det.

Det finns uppenbara risker med ett sådant arbetssätt. Den självklara helhetstanken och samarbetet över gränser och med andra grupper försvinner. Den «egna anläggningen» blir allenarådande och viktigast. Chauvinistiska tankegångar hindrar helhetssynen. Om ingenting görs för att vidga perspektiven, kan ekomuseet så småningom utgöras av ett antal från varandra avgränsade, men välbevarade fysiska miljöer vilande tysta i landskapet, likt reliker från svunna epoker, i saknad av varje förmåga att förmedla kunskap om helheten och om de sammanhang som ger strukturen i landskapet.

Men å andra sidan kan inte en levande historiedebatt, där hela tiden våra förhållningssätt till det förflutna omstöps, omvärderas och skapar nya frågor, hållas vid liv, om inte tankarna finns manifesterade i fysiska uttryck. Det förgångna måste till 
38 viss del finnas bevarat $\mathrm{i}$ form av påtagliga spår, arkivalier, arkeologiskt material, byggnader, spår av resursutnyttjande och verksamheter. Utan dessa fysiska bevis för att det förflutna har existerat, blir det svårt att förstå vilka möjliga utvecklingslinjer vi har att vänta oss.

I Sverige står vi idag inför tydligt uttalade krav på att satsningar på kulturarvet ska generera ekonomisk utveckling med fler arbetstillfällen och ökad omsättning i serviceföretagen i form av turistintäkter. Betraktar vi ekomuseerna enbart som kulturturistiska satsningar kan det bli svårt att förena delaktigheten med vinstintressena och kunna motivera folkbildningsinsatserna ur ett ekonomiskt perspektiv. Är det överhuvudtaget möjligt att kombinera ett vinsttänkande med ett folkbildningsideal? Jag har inget svar på den frågan, utan kan bara konstatera att det finns olika exempel på blandformer, där detta tycks vara möjligt. Vi är i Sverige ovana vid att förena en ekonomistisk syn med våra kulturpolitiska mål, men vi har en del att lära av dem som idag arbetar med sådana kombinationer.

Kan vi överhuvudtaget välja väg? Blir inte ett ekomuseum, där fokus ligger på vården av det materiella kulturarvet, ganska torftigt? Och hur ska vi ens kunna drömma om att förmedla historia, om vi saknar de fysiska spåren och enbart sysslar med ideologisk debatt? Och när det gäller vår överlevnad som museiorganisation? Kan vi ensidigt lita på bidrag från stat och kommuner i framtiden, eller måste vi sätta ett pris på vårt arbete och se ekomuseet som en av flera möjligheter till ekonomisk utveckling i den region där vi befinner oss? Det finns nog bara en väg att gå och den innebär en balansgång mellan ytterligheterna.
Ty oavsett om man lägger störst vikt vid de materiella lämningarna och fokuserar arbetet på upprustningar, restaureringar, rekonstruktioner av historiska anläggningar och platser eller om man väljer att arbeta mer med folkbildningen, historiesynen och de intellektuella processerna i lokalsamhället - så måste det bli en blandning av båda fokuseringarna, eftersom ensidigheten skulle göra museet självdöende. I ett levande ekomuseum är både kroppen och själen nödvändiga och beroende av varandra.

I min önskevision av framtidens ekomuseum finns ett sådant fruktbart samspel mellan vården av det kroppsliga och det själsliga. Där syftar upprustningar och vårdprojekt även till att skapa plattformar och scener för aktiviteter, men också till att bearbeta och påverka våra synsätt på det förflutna. När bevarandet och dokumenterandet får ett egenvärde, stelnar intellektet och rörelsen avstannar.

Det kanske är just därför som ekomuseerna är så spännande. Deras ideologi och målsättning bygger på ett ständigt pågående ifrågasättande av det etablerade museitänkandet och ett tänjande av gränserna för hur ett museum kan definieras. Ekomuseerna utgör också spännande exempel på hur en lokalbefolkning kan arbeta musealt, utan att arbetet för den skull behöver präglas av lokal chauvinism. Det kan istället bli inledningen till ökat samarbete mellan de ingående delarna.

Helhetsperspektiv, sammanhang och delaktighet är centrala nyckelbegrepp för ett ekomuseum. Att vidga världen genom att sätta in det lilla i det större sammanhanget. Att få varje plats att förstås utifrån sin betydelse för den ekonomiska och politiska utvecklingen. I Bergslagen är detta kanske extra tydligt, eftersom järn- 
hanteringen redan från förhistorisk tid har haft stor internationell betydelse och räckvidd. Detta är nyttig kunskap som leder till ökad internationell förståelse och som breddar synfältet.

Ekomuseerna är exempel på «nya» museer. De riktar sig mot framtiden och kräver för $\sin$ existens en aktiv och deltagande befolkning. Deras övergripande mål borde vara att föra in en levande historiesyn i ett modernt samhälle.

För några år sedan - 1992 - hölls ett nordiskt ekomuseimöte i Samsö i Danmark. Marc Maure - en av deltagarna i seminariet - pekade i sitt anförande på tre faktorer som ger ekomuseet dess speciella identitet;

1) Det är en idé mer än en institution

2) Det är en process för en befolkning

3) Det är en mentalitet för museifolk

De här tre faktorerna sammanfattar ekomuseernas grundläggande syfte och är lite av ett rättesnöre för mig själv.

I år är det tio år sedan Ekomuseum Bergslagen bildades. Vilken eller vilka frågor kommer att bli mest centrala att arbeta med under nästföljande tioårsperiod? Mycket pekar på att miljöfrågorna alltmer kommer att överskugga andra globala problem. Ekomuseernas uppgifter borde därför vara att öka förståelsen och kunskapen om människans roll i landskapet och tydliggöra det ekologiska sambandet mellan energi, råvaror och verksamheter. Ekomuseerna kan delta $\mathrm{i}$ arbetet med att utveckla ekologiskt hållbara framtidsstrategier. Ett förgrenat nätverk mellan lokala ekomuseer kan dessutom bidra till att lokalsamhällena finner långsiktiga och övergripande lösningar på de miljöproblem som idag upplevs som akuta.
Detta bör ingå i Ekomuseum Bergslagens framtida arbetsuppgifter tillsammans med att öka delaktigheten bland yngre människor och att skapa en bredare anslutning till ekomuseets målsättning.

Idag ingår ett femtiotal fysiska miljöer i Ekomuseum Bergslagen. Dessa platser är utvalda efter vissa kriterier som t.ex. att de ska kunna erbjuda viss service till besökare, att de ska exemplifiera järnhanteringen i Bergslagen och att de ska komplettera övriga miljöer i ekomuseet, så att en mer differentierad kunskapsbild framträder för besökare.

I framtiden hoppas jag att medlemskapet kan vidgas till att även gälla föreningar och organisationer som arbetar i linje med museets målsättning, men som inte är förknippade med en bestämd fysisk plats. Det finns idag flera sådana sammanslutningar som skulle kunna bidra till att vidga perspektiven och bredda ekomuseets innehåll. Bergslagens kvinnomuseum, som lyfter fram kvinnornas historia i Bergslagen, är ett av flera sådana exempel.

För den som bor i den här regionen borde det $\mathrm{i}$ framtiden vara naturligt att känna delaktighet i Ekomuseum Bergslagen, dvs. själva begreppet borde kunna utgöra en väsentlig del $\mathrm{i}$ invånarnas identitet.

Det jag sagt här om en breddning och en utvidgning av ekomuseets innehåll till att gälla många fler former av mänskliga aktiviteter än bergsbruk, järn- och stålindustri, är ännu så länge endast min egen vision, men ingår tillsammans med många andra utvecklingstankar i en spännande fördjupningsdiskussion som vi just nu står mitt uppe i. Frågorna som diskuteras gäller var vår tyngdpunkt ska läggas i arbetet och hur vi ska definiera ekomuseibegreppet. Ambitionen att museet ska utvecklas till ett 
40 instrument för samhällsanalys, identifiering och aktivt historiemedvetande är hög, men inte orealistisk. De första tio årens verksamhet i Ekomuseum Bergslagen har stakat ut vägen och identifierat en del av hindren. Ett processiniktat och levande museum blir aldrig färdigt eller når ända fram. Det rymmer frågor med väldig spännvidd som kontinuerligt diskuteras och prövas. Strävan efter balans mellan museets själ och kropp är grundläggande och måste hållas ständigt aktuell.

Texten är en bearbetad version av ett muntligt anförande vid Riksutställningars seminarium From Burgundy to Bergslagen, Stockholm, 30 maj 1996.

\section{SUMMARY}

\section{The ecomuseum in a vision of the future}

Museum work, like all work on historical questions, is a matter of relating oneself to the past. Retrospection varies through the ages and varies depending on who you are and the kind of society you are living in.

At the turn of the century the Nordic museum urged its visitors to use the past to "know thyself" and the Swedish Tourist Association at the same time invited their clients to "Know your country!" both being aware of the citizens' need for selfreflection in the world they lived in. The present Heritage Act in Sweden states that the preservation of our heritage is the responsibility of all. But the collective memory amounts to far more than the contents of our museums and archives. All human experience and knowledge, all working processes and all forms of expression created by man, together with our physical environment belong to those parts of the collective memory which are not catered for in those institutions. The emergence of the ecomuseums in the 1970s could be regarded as a consequence of that knowledge. A fundamental question for both the traditional museum and the ecomuseum is the role played by the material heritage which constitutes their means of transferring traditional knowledge and experience in a community. Perhaps it has to do with the current materialism - that which is not visible, does not exist. The outwardly manifested forms become important for the survival of a collective memory. Ecomuseums which are not burdened with the ownership or management of intstallations and factories however have every possibility of ensuring the survival of the memories linked to the site. In ecomuseums great emphasis is put on the active participation of people as well as on the living interpretation of history as the centre of attention. To maintain the living spirit in museum work means conducting a continual historical debate amongst the participants in the museum project in which attitudes to the past are constantly being remoulded and new questions are being asked. The author points to the fact that environmental issues increasingly overshadow other global problems. She therefore considers that one important task should be to enhance understanding and knowledge of man's role in his physical environment and the connection between energy, raw materials and human activities. The ecomuseum could play a part in developing ecologically sustainable strategies for the future. She also wants to work harder to increase participation among young people and to achieve wider support for the ecomuseum's objectives. The aim of the museum - to develop as an instrument of social analysis, identification and active historical awareness - is high but not unrealistic. A process-oriented museum is never finished. The pursuit of a balance between the body and soul of the museum is fundamental and neverending.

Ewa Bergdahl är direktör for Ekomuseum Bergslagen. Adr: Kyrkogatan 2, S-777 30 Smedjebacken Fax +46-240-663082 